\title{
INNOVATION AND INFORMATION ASPECTS OF THE STRUCTURAL ORGANIZATION OF THE WORLD POLITICAL AND ECONOMIC SPACE
}

\author{
Vyacheslav Dementyev, Nataliya Dalevska, and Aleksy Kwilinski
}

\begin{abstract}
The article analyzes the innovation and information aspects of the structural organization of the world political and economic space in terms of increasing the importance of knowledge-intensive production in meeting social needs. It develops theoretical aspects of establishing international economic relations in the conditions of deepening global confrontation between hierarchical and network structures of the global political and economic space. The institutional structure of the world political and economic space in terms of functional, normative, relational and stratification aspects is studied. It is determined that the global economy and world politics interact in accordance with the strategic direction of the global society development, the dominant position in which is occupied by information and communication technologies that provide opportunities to optimize the operation of actors in international relations and knowledge, the volume of which determines the integrated the position of the individual in the space of social inequalities, associated with a specific set of life opportunities. From the standpoint of the existential approach, it is argued that the globalization of the world economy generates a wide range of internal interests and human motivations, stimulates its purposeful influence on shaping the global information infrastructure, global productive forces and transformation of international economic relations on the natural basis of cognitive capital and social capital. The communicative and informational properties, the specifics of accumulation and the latest trends in the reproduction of social capital within the world political and economic space are considered. The paper reveals the criterion assessment of the effectiveness of rent-oriented social networks as a structural basis of the world political and economic space and the social legitimacy of international power structures for regulating the global social processes. The research results were scientifically substantiated on the basis of combining the concepts of existential approach and general scientific, special methods of scientific cognition (logicaldialectical method, method of systemic analysis, comparative method, economic-statistical method, method of theoretical generalization).
\end{abstract}

Keywords: the world political and economic space, rent-oriented social networks, world social capital, international relations actors, institutionalization

JEL Classification: A10, E02, F00 


\section{Authors:}

\section{Vyacheslav Dementyev}

Financial University under the Government of the Russian Federation, Leningradsky Prospekt 49, Moscow, Russia, 125993

E-mail:dementyevv@mail.ru

https://orcid.org/0000-0001-6438-4320

\section{Nataliya Dalevska}

Institute for International Cooperation Development, Kazimierza Wielkiego 24-26/1, Poznań, 61-863, Poland

E-mail: dalevskanm@gmail.com

https://orcid.org/0000-0002-0074-497X

\section{Aleksy Kwilinski}

The London Academy of Science and Business, 120 Baker Street, London, United Kingdom, W1U 6TU E-mail:a.kwilinski@london-asb.co.uk

https://orcid.org/0000-0001-6318-4001

Citation: Dementyev, V., Dalevska, N., \& Kwilinski, A. (2021). Innovation and Information Aspects of the Structural Organization of the World Political and Economic Space. Virtual Economics, 4(1), 54-76. https://doi.org/10.34021/ve.2021.04.01(3) 


\section{Introduction}

The current period of world economic development is characterized by the technological competition increase and the dominance of innovative competitive advantages in the world political and economic space. The innovative type of economic development is increasingly becoming the foundation that determines the economic power of the country and its prospects on the world market. Accordingly, the world economy globalization is accompanied by a growing trend of conflicts and contradictions due to the search for additional sources of investment support for structural changes and the intensification of innovation processes. However, the process of constructing hierarchical levels in the structure of international relations is continuous and dynamic, resulting in a change of innovation leaders with the subsequent formation of functional features of the mechanism structuring the world political and economic space. At the same time, radical changes in the world political and economic space are significantly related to the information sphere, which increasingly testifies to the dominant position of institutionalization of the world political and economic space and the perception of international relations actors about new social values, factors and conditions of developing the world social capital. This determines the emergence of a number of issues related to the values hierarchy in allocating global resources, to developing global institutions, forms of hierarchy and coordination of actors in international relations.

\section{Literature Review}

The creation of conceptual foundations for the structural organization of the world political and economic space has a long history. The works by J. Althusius (1995), M. Weber (1978), T. Parsons (1977), J. Schumpeter (1995).

The works by such authors as I. Wallerstein (2008), G. Arrighi (2007), M. J. Habermas (1991) are devoted to studying the features of structuring the world political and economic space. Research is primarily focused on transformation processes in the world economic system, structural heterogeneity of actors in international relations, shifted centres of gravity in the mechanisms of cyclical fluctuations from trade to the movement of liquid capital, and so on.

The study of the parameters of the structural elements' balanced cycle of the world economy as a multipolar system in the wave of "information society" is carried out in the works by $A$. Aleksander et al. (2020), S. Bogachov et al. (2020), O. Burlaka et al. (2019), O. Chygryn et al. (2020), V. Dementyev (2013; 2015; 2019), V. Dementyev \& A. Scherbakov (2017), V. Dementyev \& A. Kwilinski (2020), W. Drozdz (2019; 2020), H. Dzwigol (2019a; 2019b; 2020a; 2020b; 2020c; 2020d; 2021), H. Dzwigol et al. (2019a; 2020a; 2020b), M. Gorynia (2019), M. Gorynia et al. (2019), N. Kashchena et al. (2019), J. Kaźmierczyk \& A. Chinalska (2018), S. Koev et al. (2019a; 2019b), V. Koibichuk et al. (2021), O. Kvilinskyi (2012), O. Kvilinskyi \& S. Kravchenko (2016), A. Kwilinski (2018a; 2018b; 2019), A. Kwilinski et al. (2019a; 2019c; 2019e; 2019f; 2020a; 2021), A. Kwilinski \& A. Kuzior (2020), V. Lakhno et al. (2018), O. Melnychenko (2019; 2020; 2021), R. Miskiewicz (2017a; 2017b; 2018; 2019; 2020a), R. Miśkiewicz \& R. 
Wolniak (2020), V. Tkachenko et al. (2019a; 2019b; 2019c; 2019d; 2019e), N. Trushkina (2019), N. Trushkina et al. (2020), and others.

The theoretical search for modern features of structuring the world political and economic space is determined by such socio-integration and socio-institutional trends in the world economic system as preferring the concept of sustainable development in structuring the integration interests of actors in international relations within the world political and economic space (Abazov, 2021; Arefieva et al., 2021; Boiko et al., 2019; Borychowski et al., 2020; Czyżewski et al., 2019; 2020; Dalevska, 2013; Dalevska et al., 2019; Dzwigol, \& DźwigołBarosz, 2018; 2020a; 2020b; Dzwigol et al., 2019a; 2019c; Kharazishvili et al., 2020; 2021; Kondratenko et al., 2020; Kuzior et al., 2019; Kwilinski et al., 2019b; 2019d; 2019f; 2020b; 2020c; 2020d; 2020e; Kyrylov et al., 2020; Lyulyov \& Pimonenko, 2017a; Lyulyov \& Shvindina, 2017b; Lyulyov et al., 2018; 2020a; 2020b; 2021a; 2021b; Mlaabdal et al., 2020; Miskiewicz, 2020b; 2021; Pająk et al., 2016; 2017; Pimonenko \& Lyulyov, 2019; Ponomarenko et al., 2018a; 2018b; Prokopenko \& Miskiewicz, 2020; Saługa et al., 2020; Savchenko et al., 2019; Shmygol et al., 2020; Wyrwa \& Kaźmierczyk, 2020), strengthening social security system using the dominant characteristics of the world social capital, etc.

For adherents of existentialism, the key concept in identifying the specificity of structural transformations of the world political and economic space with its inherent uncertainty, unpredictability and dynamism is the concept of "cognition". The content of cognitions belongs to the mental space of a man. According to J. Dinsmore's definition, "mental spaces are areas that are used to combine information of one kind or another. Within these spaces, different objects and the interaction between them can be interpreted as existing, despite the status of these objects and interaction in the real world" (1995). Cognitive approach to the methodological problems of international political economy, focuses on the mind, consciousness, knowledge of actors in international relations as the motivating factors of their activity in world political and economic space. However, inter-subjective dialogue is realized in the communicative type of public consciousness, which implies the need to focus research on the problem of increasing the interdependence of subjects and objects of international economic integration, given the institutional structure of international relations.

However, at the local level, the source element of shaping the institutions of the world political and economic space is the dominant values of social capital. Current situation conditions the topicality of studying social capital as an aggregate creative potential of society, which determines the ability of people to produce and absorb knowledge, forms and methods of labour organization and new technologies. G. Arrighi (2007), Wallerstein (1983, 2008), R. Putnam (2001) made a significant contribution to the development of trends in reproducing social capital.

It should be noted that knowledge about social capital in the conditions of network competition allows determining the factors of power struggle; explaining the functioning of contradictions between actors of international relations, which are a consequence of stability and conflict; taking measures to prevent global conflicts, improving understanding of 
legitimacy framework of the world order, etc. In this aspect, the German scientist K. Schubert notes that the concept of networks in modern research tries to compensate for the obvious shortcomings of traditional approaches. These are, in particular, theories about the processes of interests' coordination (Schubert, 2004). This theoretical approach allows us to consider the subject as complex and changeable, in fact, decentralized, i.e. forced to constantly restore the balance between internal and external influences (information flows) through the approval and rethinking, improvement and clarification, recognition and denial of rules and forms of interaction, when external and internal are the poles of attention of a subject, who tries to find and to centre the desired balance within the world political and economic space in terms of qualitative diversity of elements of the world economic system and multi-variance of evolutionary trends in global development.

\section{Methodology}

The determining role of institutional structure of the world political and economic space in swaying the formation, functioning and development of the world economic system is substantiated by a combination of existentialism concepts (Figure 1).

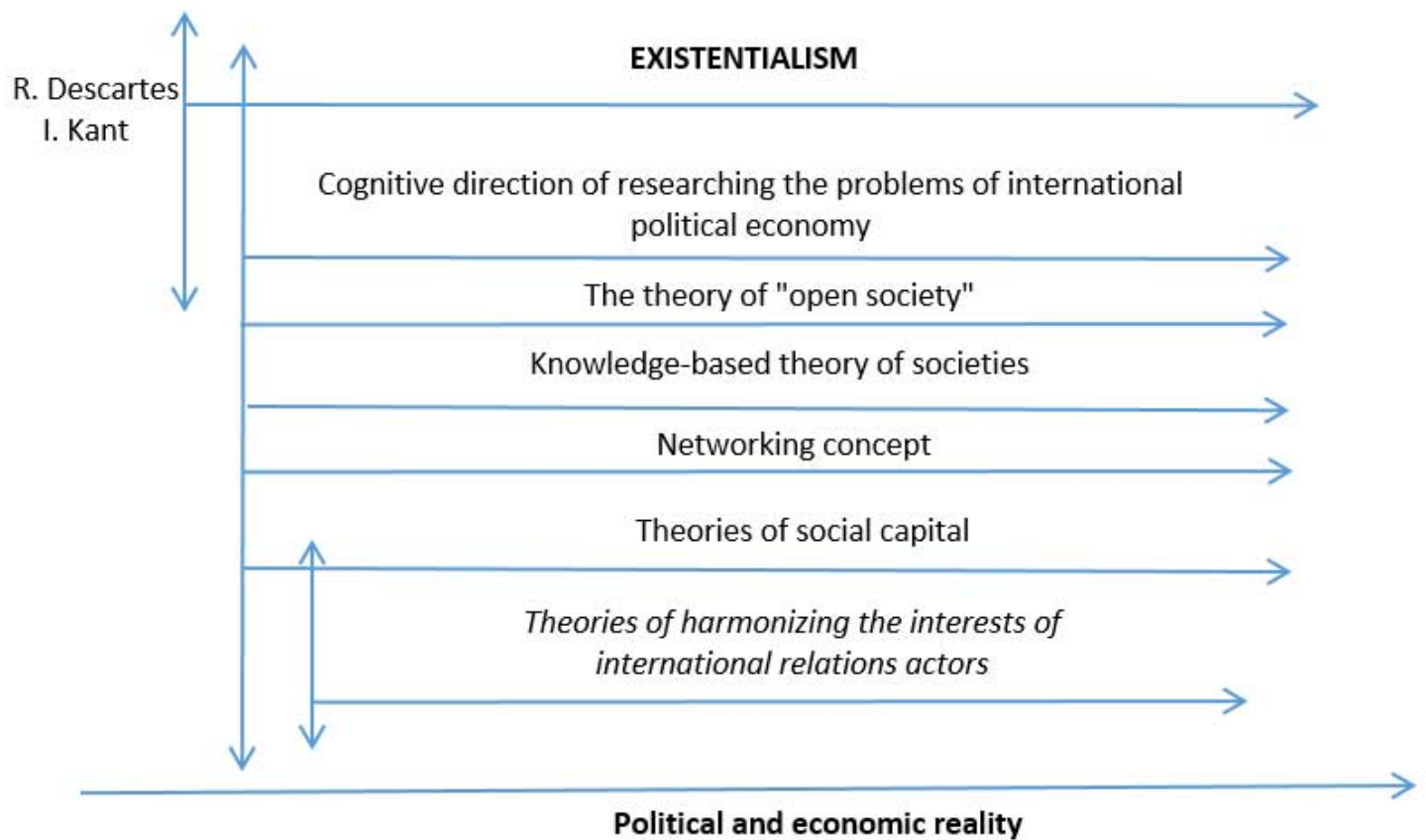

Figure 1. Development of existentialism in the context of structuring the world political and economic space.

Source: own elaboration.

The methodological basis of the study consists of general scientific methods (analysis and synthesis, induction and deduction, system approach), which corresponds to its theoretical 
focus, and is grounded on a number of methods of scientific cognition (systemic, economicstatistical, comparative, theoretical generalization) due to the specifics of economic science.

\section{Results}

The world political and economic space is a relatively ordered set of an unlimited number of hierarchies of the world economic system, which, however, belong simultaneously to the hierarchies of macro-, meso-, and micro-levels. Moreover, such hierarchies are in a state of constant transformation: disappearance, formation, change of configurations, crossing. In particular, the structuring of the world political and economic space in the context of the world economy globalization implies that countries become not only interdependent through forming a system of international integrated production, growth of world trade, intensification of international capital movements and technological innovations, etc., related to the processes of innovations diffusion and synchronization of technological, economic, political, social transformations in the world economic system.

Thus, the structuring of the world political and economic space occurs under the influence of economic, political, social, mental, cultural and general civilizational factors. This conditions an extraordinary variety of structural changes inherent in modern world economic development, even a certain disintegration of the world social system. On the one hand, the formation of the world political and economic space appears as an objective process - the result of the development of productive forces and production relations; on the other hand, as a subjective process caused by the dominant vector of policy pursued by the most powerful countries - "global players" on the world arena.

It should be noted that the main feature of modern political and economic dominance in the world is a significant separation of the countries with innovation-oriented economies, which are actively forming new global markets, from less powerful countries, which are forced to some extent to be dependent on the position of "global players". In the countries that belong to the innovative leaders, there is a high concentration of the most profitable types of business, mainly high-tech structure of national production and concentration of the largest financial flows. This, in particular, is about the redistribution of resources in favour of developing countries on the basis of post-industrial principles, and the accumulation of backwardness on the other pole - in the countries with traditional industrial technology and pre-industrial development (Cattaneo et al., 2010). Under these conditions, leadership becomes more personalized, but the path to power lies through the formation of rentoriented social networks: inter-individual, inter-group, inter-institutional interaction of actors in international relations within the world political and economic space.

Rent-oriented social networks as a structural basis of the world political and economic space are based on:

1) transforming knowledge into financial and managerial innovations and forming, on this basis, global control over money and its flows;

2) controlling innovation globally in order to concentrate knowledge in highly developed countries;

Vyacheslav Dementyev, Nataliya Dalevska, and Aleksy Kwilinski

Virtual Economics, Vol. 4, No. 1, 2021 
3) a special kind of global rents - innovative, intellectual, resource, financial, political, informational, environmental, etc.;

4) economic networks, through which global rents are realized.

According to Wallerstein's world-system theory, the hierarchization of space in the structure of production processes has led to increasing polarization between the core (profit-making zone) and peripheral zones (loss-making zones) of the world economy not only along the distribution line, but, also along the line of localization of capital accumulation. The key to understanding this central mechanism is in the very structure of the capitalist world-economy, in the imaginary personification in the capitalist world-system of the economic sphere and the political sphere. However, in the real world, almost all commodity chains of any importance breach state borders, and this has been the case since the time historical capitalism started to exist. At the same time, the transfer of profits to the core concentrated capital there and created disproportionately large funds for further mechanization. This provided producers in the core areas with additional advantages in manufacturing existing products and allowed them to create more and more new rare products, by means of which they renewed the whole process (Wallerstein, 2008). After all, non-equivalent exchange between the two zones is the main mechanism for the global rent transfer from the periphery of the core.

The widening gap between developed and developing countries is a dominant destabilizing factor that stimulates asymmetric trends in the world economic system. Some countries, pursuing their national interests, receive benefits and gains, while others become dependent on the supply of technology and external assistance. As a result, the structure of wealth in the countries with the lowest incomes is dominated by natural resource capital, while the structure of wealth in highly profitable countries is dominated by human capital. According to the World Bank data, in the structure of national wealth of developed countries, human capital averages $70 \%$. Developed countries have concentrated more than $90 \%$ of the world's scientific potential, control $80 \%$ of the global high-tech market (The World Bank, 2019). Leading industries and activities through which the capital is accumulated comprise the core of the technological system (Table 1).

Naturally, each technological system has its own characteristics of the social life of society, the role of the government in managing production, the dominant countries, their policies, promising research areas and the degree of their importance in production. According to the concept of K. Freeman, the impetus for economic development is given by the emergence of basic innovations in certain industries. The aging of technological systems in some countries and the emergence of such systems in others lead to further uneven global economic development (Freeman et al., 2001). Each subsequent technological system originates in the depths of the current one, and takes effect when the latter exhausts its capacities and loses efficiency in increasing the rate of return.

Now in the structure of the economy of the countries - world technological leaders, there is observed the development of the main industries of the sixth technological system, associated with the spread of genetic engineering, nanoelectronics, global information and 
communication networks, fundamentally new sources of energy and materials. The growing actualization of these positions is determined by the logic of institutional transformations of the world political and economic space, which bear the signs of the fundamental laws of the evolutionary process. First of all, it is about gaining the dominance by creative work, which asserts itself through innovation, technology transfer, international patenting, and so on. It is about transformations of industrial and reproductive work into creative, which organically corresponds to the growth of intellectual potential of the individual, realized in the world political and economic space.

Table 1. Characteristics of the leading technological systems

\begin{tabular}{|c|c|c|c|c|c|}
\hline \multirow{3}{*}{$\begin{array}{c}\text { Period of } \\
\text { dominance, } \\
\text { years }\end{array}$} & \multicolumn{5}{|c|}{ Technological System } \\
\hline & First & Second & Third & Fourth & Fifth \\
\hline & $1770-1830$ & $1830-1880$ & $1880-1930$ & $1930-1990$ & $1990-\ldots$ \\
\hline $\begin{array}{l}\text { The core of } \\
\text { the system }\end{array}$ & $\begin{array}{l}\text { Textile industry, } \\
\text { textile machine } \\
\text { building, pig iron } \\
\text { smelting, iron } \\
\text { processing, canal } \\
\text { construction, } \\
\text { water engine }\end{array}$ & $\begin{array}{l}\text { Steam engine, } \\
\text { railway construction, } \\
\text { transport, machine- } \\
\text { building, steamship } \\
\text { construction, coal } \\
\text { machine tool } \\
\text { industry, ferrous } \\
\text { metallurgy }\end{array}$ & $\begin{array}{l}\text { Electrical, heavy } \\
\text { machine } \\
\text { building, } \\
\text { production and } \\
\text { steel rolling, } \\
\text { power lines, } \\
\text { inorganic } \\
\text { chemistry }\end{array}$ & $\begin{array}{l}\text { Car and tractor } \\
\text { construction, non- } \\
\text { ferrous metallurgy, } \\
\text { production of } \\
\text { durable goods, } \\
\text { synthetic materials, } \\
\text { organic chemistry, oil } \\
\text { production and } \\
\text { refining }\end{array}$ & $\begin{array}{l}\text { Electronic } \\
\text { industry, fibre } \\
\text { optic } \\
\text { computers, } \\
\text { software, } \\
\text { telecommunicat } \\
\text { ions, robotics, } \\
\text { gas production } \\
\text { and processing }\end{array}$ \\
\hline $\begin{array}{l}\text { The core of } \\
\text { the new } \\
\text { device } \\
\text { being } \\
\text { formed }\end{array}$ & $\begin{array}{l}\text { Steam engines, } \\
\text { mechanical } \\
\text { engineering }\end{array}$ & $\begin{array}{l}\text { Steel, power } \\
\text { engineering, heavy } \\
\text { engineering, } \\
\text { inorganic chemistry }\end{array}$ & $\begin{array}{l}\text { Automobile } \\
\text { construction, } \\
\text { organic } \\
\text { chemistry, oil } \\
\text { production and } \\
\text { refining, non- } \\
\text { ferrous } \\
\text { metallurgy, road } \\
\text { construction }\end{array}$ & $\begin{array}{l}\text { Radars, pipeline } \\
\text { construction, } \\
\text { aviation industry, gas } \\
\text { production and } \\
\text { processing }\end{array}$ & $\begin{array}{l}\text { Biotechnology, } \\
\text { space } \\
\text { technology, fine } \\
\text { chemistry, } \\
\text { nanotechnology }\end{array}$ \\
\hline
\end{tabular}

Source: own processing according to Balabanova (2011).

In 2019, the number of international patent applications for inventions filed under the Patent Cooperation Treaty (PCT) increased by $23 \%$ compared to 2005 . The PCT system creates significant benefits for patent offices (reduction of staff workload), applicants (cost reduction and awareness raising) and the national economy as a whole (creating favourable conditions for the acquisition of new technologies, attracting foreign investment, etc.). Leaders in patenting inventions are China (their share in the total number of applications is $43.4 \%$ ), the United States (19.3\%), and Japan (9.6\%). These three countries account for more than half of all applications (72.3\%) submitted in 2019 using the PCT. (World intellectual property organization, 2019)

Countries that implement strategies for innovative development of national economies have effective national innovation systems, government mechanisms for regulating the innovation 
activities of market participants, the highest indicators of the Global Competitiveness Index (GCI) (Table 2).

Table 2. Top 10 countries with innovation-oriented economies, 2019

\begin{tabular}{lcc}
\hline Country/Economy & Global Innovation Index, Rank/Score & $\begin{array}{c}\text { Global Competitiveness Index, } \\
\text { Rank/Score }\end{array}$ \\
\hline Switzerland & $1 / 67.24$ & $5 / 82.3$ \\
\hline Sweden & $2 / 63.65$ & $8 / 81.2$ \\
\hline The USA & $3 / 61.73$ & $2 / 83.7$ \\
\hline The Netherlands & $4 / 61.44$ & $4 / 82.4$ \\
\hline The United Kingdom & $5 / 61.30$ & $9 / 81.2$ \\
\hline Finland & $6 / 59.83$ & $11 / 80.2$ \\
\hline Denmark & $7 / 58.44$ & $10 / 81.2$ \\
\hline Singapore & $8 / 58.37$ & $1 / 84.8$ \\
\hline Germany & $9 / 58.19$ & $7 / 81.8$ \\
\hline Israel & $10 / 57.43$ & $20 / 76.7$ \\
\hline Source: own processing according to data of the World intellectual property organization (2019) and World \\
Economic Forum (2019).
\end{tabular}

It should be borne in mind that the political capabilities of national institutions determine the competitive advantages in the global market of both individual firms and the economy as a whole, through such tools as political risk hedging, international fines and compensation, parity financial responsibility of coalition members for social economic consequences of joint actions, etc. The possibility of using these tools is provided, first of all, by the independent position of countries in the geopolitical space of international transactions, economic and military power of states.

As defined by S.J. Gould, the world appears as a set of quasi-stable systems that resist as much as they can to the limit of their strength, and then quickly move to a new balanced state (1986). Endurance, stability, sustainability in self-organizing systems is based not on their resilience to external pressure, but due to changes aimed at improving intra-system ties within the world political and economic space. Under these conditions, the fundamental problem is to find a way to absorb excess capital, i.e., new additional areas of profitable use of capital, which would keep the system from plunging into crisis. As a rule, the next recession or rise of the world economic system begins in the core states (i.e., global leaders), and then spreads to other regions, including the periphery and competing countries of the core states. At the same time, it is the leader (leaders) who has the deepest cyclical decline. Competitors from the core countries, as well as certain semi-peripheral regions, have the opportunity to break through and possibly even take the place of the previous leader (Frank et al., 1994).

At the same time, progress in the division of labour, based on information and innovation development, leads in modern society to the infinite growth of objects of purchase and sale. This is especially true of financial and information markets, which shape their world, their 
environment, sometimes weakly related to the processes in the real economy. As a result, along with the commodity and money fetishism usual for the market economy, a fetishism of a special kind - financial and informational - is becoming more widespread (Porokhovskyi, 2012). Importantly, the possession of world currency has a positive effect on the political and economic image of the country in the world, allows collecting and processing the widest amount of information on the economic activities of foreign countries, companies, political forces and individuals.

First, the state that issues the world currency receives direct income from seigniorage; secondly, the possession of the world's reserve currency allows creating a strong sector for the provision of services related to this currency; third, in many cases, the issuing state benefits from the fact that foreign states hold gold and foreign exchange reserves in government securities denominated in this currency, and the yield on these securities is often lower than national inflation. Finally, the most important thing is that owning the world currency allows financing public debt and the balance of payments deficit with own currency.

The immediate political benefit lies in the fact that the issuer of the world currency is able to impose financial sanctions on certain countries and companies, as their settlements are made through the banking system of the issuing country. In case of any political necessity, such settlements can be stopped, and trade and financial transactions of countries (companies) objects of sanctions will be frozen. Under these conditions, one of the compulsory stages of institutional dynamics and transformation of the world political and economic space is to establish social order relations, adapted to the hierarchical ties among the actors in international relations, which leads to the deep essence of social capital, given the principles of communicative legitimacy.

After all, the category of social capital expresses the nature and content of relations among people and social groups as permanent bearer of qualitatively different types of social activities, differing in social status and social functions. No matter in which sphere of society the interaction among the subjects of the world economic system takes place, it is always social in its nature, as it expresses the connections between individuals and groups of people, i.e., the connections mediated by the goals that each of the interacting parties seek to adapt to their own needs.

In essence, communicative legitimacy is a conscious and controlled process that is determined by the level of the ratio between needs, interests and goals of institutional actors. This characterizes communicative legitimacy as a multilevel system with a wide range of power relations among the subjects of social management within the world political and economic space. According to the definition by W. Beck, power arises from the sum total of actions and decisions approved (2007). Thus, the arrangement of power structures is formed by the position, motives, goals, interests, preferences, ideology, value system, as well as programs of activities and forms of organizational behaviour of actors within the world political and economic space. The main focus is on the institutional environment, as well as the impact of formal and informal institutions on the accumulation of social capital. However, the objective 
complexity of social capital, i.e., complexity as a holistic structure, significantly affects the difficulties for understanding it.

Social capital comes in many forms, both as a resource and an institutional environment. At the same time, in the spatial dimension, it is characterized as a totality of knowledge, ideas, actions, results from revealing the mechanisms for deepening the international division of labour. Thus, the spatial dimension of social capital involves a multidimensional kind of socioterritorial community of people who differ in the totality of natural and historical conditions of socio-economic diversity. A common feature of such entities is the availability of certain interests in the form of the purpose of activities, social norms and values that regulate it.

Networks, norms and trust constitute a "triad of social capital" (Burkynskyi \& Horiachuk, 2013). All elements of the "triad" are connected with each other. Networks build trust among participants and promote dissemination of prosocial norms of behaviour, while common values and mutual trust expand social networks and contacts. Trust and norms of subjects' behaviour are elements of the institutional environment of the social system.

Social capital is one of the fundamental categories of international research on trends in world economic development. On the one hand, social capital is a complex system of interpersonal, intragroup and intergroup interactions, which necessitates the establishment of economic, social, political communication among actors in international relations. On the other hand, social capital is grounded on its objective inequality, heterogeneity, as a clear manifestation of inequality in access to resources, the conditions of their accumulation and use. From this point of view, the structuring of social capital takes place within the world political and economic space.

Since 2009, large-scale studies of social capital by the British think tank Legatum Institute have been conducted on the following indicators: level of trust; the scale of donations; degree of volunteering development; dissemination of the practice of assistance to third parties; social support of relatives; development of the marriage institution; religiosity in society; social cohesion and interaction in the family and community. Statistics and survey results are summarized in a single index of social capital development, which is part of the Legatum Prosperity Index. Economic indicators (GDP, household income) as well as less precise criteria (for example, the results of life satisfaction surveys) are used for evaluation. The 89 criteria are divided into eight groups: economics, business and opportunity, governance, education, health, security, personal freedoms, and social capital. In 2020, the first place in the ranking of prosperous countries in the world, as well as last year, was taken by Norway, followed by Switzerland, Canada, Sweden and New Zealand. The Democratic Republic of the Congo, the Central African Republic and Chad closed the ranking (Legatum Institute, 2019).

In particular, in countries with a developed institutional environment, a high level of trust in government and a significant amount of GDP per capita, there dominate "Putnam groups", whose goal is the public good. At the same time, it is not uncommon for actors to pursue their own goals and mobilize the bonding social capital of the "Olson group". These groups can 
compete with other interests in the economy and society for limited resources - in this case, social capital does not create new value, and its public return is zero or even negative. Thus, when analysing the latest trends in the social capital reproduction, it is methodologically important to take into account its ability to influence any aspect of world social development both positively (order, stability, conflict resolution, government efficiency, security) and negatively (crisis of power structures and power legitimacy, instability and functional disorder of the mechanisms of governing society, transformation of functional contradictions into structural social disturbances).

Social capital, methods and forms of its appropriation, optimal distribution are the basis for reducing (or increasing) transaction costs. Thus, the basis for social capital reproduction is the formation of stabilization mechanisms that regulate the diversity of elements, connections and relations among the subjects of the world economic system, including the creation of a social information system. The significance of this information is determined by how effectively the world economic system functions and develops.

However, the reproduction of world social capital on a cyclical basis contributes to the complexity and diversity of systemic features of the individual and society, affecting the systemic inequalities of social opportunities for human development within the global political and economic space. In this sense, social capital is an essential characteristic of human development. After all, the more money a country invests in science, education, culture, accelerates the pace of social information, the higher is the human development index (HDI). In particular, HDI has grown since 1970 - by $41 \%$ in general and $61 \%$ in countries with low HDI, which reflects progress in health, education and income (United Nations Development Programme, 2019).

In essence, the change of values at the level of world social capital is due to the transformation of information resources and information infrastructure into one of the most important areas of interstate struggle for world leadership and achieving on this basis political, economic, social goals by the opposing parties. Thus, it turns out that world social capital is an intersystem characteristic of an individual, in which integrity is understood as the relationship of the general, special and individual in a human being. For this reason, the reproduction of world social capital is based on the principles of procedurality, systemacy and complexity, proneness to conflict and creativity of the actors of international relations within the world political and economic space.

Thus, the reproduction of world social capital depends on the intensity of circulation between the structural subsystems of the world political and economic space and the presence of feedback with human capital.

The actions of various institutional actors, primarily state institutions, can directly or indirectly affect the strength of the relationship between social and human capital within the global political and economic space. Under these conditions, the development of criteria for the social legitimacy of international power structures for regulating world social processes 
becomes especially relevant. The solution to this problem involves the implementation of such measures as:

- introducing standards of social services, which should establish framework requirements for the quality and conditions of service provision;

- developing requirements for monitoring, control and evaluation of social service providers;

- dividing powers among international, state and local authorities regarding responsibility for the organization of social services;

- ensuring, at the legislative level, transparency and accountability of the social services system (processes of planning, organization of social services, monitoring of their quality should take place with the participation of all responsible structures with the involvement of public control).

It should be borne in mind that in complex systems of social management with a ramified hierarchical structure of world social capital, the communicative legitimacy of international power structures has a variety of organizational interactions:

- vertical (or subordinate) interaction that occurs between the object and the subject of management of different hierarchical levels of the management system;

- horizontal (or coordination) interaction carried out at each hierarchical level of organizational formation among the objects of management, i.e., among structural units of the organization;

- diagonal (or consultative) interaction, which is realized in the form of consultations among institutional actors within the world political and economic space.

Consequently, the conditions for the reproduction of world social capital at the beginning of the XXI century are characterized, on the one hand, by the development of the information sphere, strengthening the interdependence of the world economic system, introduction of mechanisms to legitimize international power structures, and on the other hand, by significant impact of the global migration processes, mosaic character of social structure and social norms in the world political and economic space.

Based on this, it is worthwhile highlighting such new trends in the reproduction of social capital within the world political and economic space as:

- forming a world information network, ensuring access of institutional actors to international educational and cultural programs;

- growing economic influence of social networks on the establishment of a legitimate international economic order, the introduction of communication technologies of power within the world political and economic space;

- institutionalizing the normative structure of world social capital, which is manifested in the generation of qualitatively new opportunities for human and social development;

- developing civic communication and initiative, expanding functions of civic structures and their cooperation with government institutions within the world political and economic space. The intellectual development of a human being, the spread of technological innovations based 
on the economic feasibility of social justice, social solidarity, social trust become the priority value;

- changing values and transforming social institutions that perform integrative functions in society, based on the transcendental justification of the legitimation strategy of world economic development.

Accordingly, it is appropriate to determine that the world political and economic space embodies a set of options for business entities to choose the methods of making optimal decisions that would ensure the direction of their competitive advantages. On this basis, rentoriented social networks can be considered as:

- a systemic, dynamic formation based on the innovative culture of the individual, who has innovative needs, abilities, knowledge, social values, communication and desire for selfrealization;

- a multicomponent structure that consists of: information and communication technologies, scientific and technical, organizational, institutional innovations, social and financial institutions;

- an integrative subsystem in the world economic system, which is dialectically interconnected with social processes, characterizes the creative activity of actors in international relations and influences the process of forming world social capital.

Thus, it is rent-oriented social networks that ensure the reproduction and accumulation of world social capital in the context of the growing role of intellectual rent in the structuring of the world political and economic space.

\section{Conclusions}

The structuring of the world political and economic space makes the foundation for resolving the contradictions between the actors of international relations. The functional features of these contradictions depend on the goals of the actors' activity, as well as their place in the overall structure of the power field. The analysis of the dynamics and trends of structuring the world political and economic space is based on the information openness of the actors of international relations. After all, the specific features of the formation, functioning and development of the world economy are related to the institutional structure of the world political and economic space. Global social changes, associated with the search for ways to harmonize one's own value system, provide a basis for choosing alternative courses of action, for selecting and evaluating these alternatives. In the course of human development there occurs a restoration of correspondence among various aspects of life: expanding the range of skills, abilities, knowledge, methods of action and activity in general, i.e., the operational side (or the opposite process - the narrowing of opportunities); modification of motivation - needs, goals, interests, motives - in accordance with the desires and capabilities of people in a particular area of their life. Analysis of social development shows that labour polarizes a person and the nature and at the same time affirms their inseparable unity, strengthens their 
connection, translates natural ties into social communication, develops a system of power relations, the legitimacy of which is manifested in achieving social balance during adaptation of the world economy to evolutionary change. In this sense, social capital is an essential characteristic of human development. World social capital is an intersystem characteristic of a human being, in which integrity is understood as the relationship of the general, special and individual in a person. For this reason, the reproduction of world social capital is based on the principles of procedurality, systemacy and complexity, proneness to conflict and creativity of institutional actors within the world political and economic space.

\section{Funding}

This research received no external funding.

\section{Conflicts of Interest}

The authors declare no conflict of interest.

\section{References}

Abazov, R. (2021). Education for sustainable development and ICT: The case of MDP program at alFarabi KazNU. Herald of Journalism, 58(4), 34-43. https://doi.org/10.26577/HJ.2020.v58.i4.04

Aleksander, A., Krawczyk, D., Kuzior, A., \& Kwilinski, A. (2020). The Conditions Affecting the Functioning of the Mass Media and Social Media Based on Empirical Research Conducted in Ukraine. In Khalid S. Soliman (Ed.), Proceedings of the 36th International Business Information Management Association (IBIMA) 4-5 November 2020 (pp. 10330-10342). Granada, Spain: IBIMA Publishing.

Althusius, J. (1995). Politica. Indianapolis: Liberty Fund.

Arefieva, O., Polous, O., Arefiev, S., Tytykalo, V., \& Kwilinski, A. (2021). Managing Sustainable Development by Human Capital Reproduction in the System of Company's Organizational Behaviour. IOP Conference Series: Earth and Environmental Science, 628, 012039.

Arrighi, G. (2007). Adam Smith in Beijing: Linages in twenty-first century. London: Verso.

Balabanova, N. (2011). Ispolzovanie koncepcii tekhnologicheskih ukladov v razreshenii ekonomicheskih krizisov [Using the Concept of Technological Structures in Resolving Economic Crises]. Visnik Mariupol's'kogo derzhavnogo universitetu, 2, 12-19.

Beck, U. (2007). Vlast i ee opponenty v epohu globalizma. Novaya vsemirno-politicheskaya ekonomiya Power and Its Opponents in the Era of Globalism. New World Political Economy]. Moscow: Progress-Tradiciya. Izdatelskij dom "Territoriya budushchego." [in Russian].

Boiko, V., Kwilinski, A., Misiuk, M., \& Boiko, L. (2019). Competitive Advantages of Wholesale Markets of Agricultural Products as a Type of Entrepreneurial Activity: The Experience of Ukraine and Poland. Economic Annals-XXI, 175(1-2), 68-72. https://doi.org/10.21003/ea.V175-12

Bogachov, S., Kwilinski, A., Miethlich, B., Bartosova, V., \& Gurnak, A. (2020). Artificial Intelligence 
Components and Fuzzy Regulators in Entrepreneurship Development. Entrepreneurship and Sustainability Issues, 8(2), 487-499. http://doi.org/10.9770/jesi.2020.8.2(29)

Borychowski, M., Stępień, S., Polcyn, J., Tošović-Stevanović, A., Ćalović, D., Lalić, G., \& Žuža, M. (2020). Socio-Economic Determinants of Small Family Farms' Resilience in Selected Central and Eastern European Countries. Sustainability, 12(24), 10362. doi:10.3390/su122410362

Burkynskyi, B., \& Horiachuk, V. (2013). Sotsialnyi kapital: sutnist, dzherela ta struktura, otsinka [Social Capital: Essence, Sources and Structure, Evaluation]. Ekonomika Ukrainy, 1, 67-81. [in Ukrainian].

Burlaka, O., Kuzior, A., Hanych, O., Kravchenko, S., \& Melnychenko, O. (2019). Implementation and legal regulation of e lectronic insurance in Ukraine. Journal of Legal, Ethical and Regulatory Issues, 22(Special Issue 2), 1-5. Retrieved from https://www.abacademies.org/articles/Implementationand-legal-regulation-of-electronic-insurance-in-Ukraine-1544-0044-22-SI-2-356.pdf

Cattaneo, O., Gereffi, G., \& Staritz, C. (2010). Global Value Chains in a Postcrisis World: A Development Perspective. USA: The World Bank, The International Bank for Reconstruction and Development.

Chygryn, O., Bilan, Y., \& Kwilinski, A. (2020). Stakeholders of Green Competitiveness: Innovative Approaches for Creating Communicative System. Marketing and Management of Innovations, 3 , 356-368. https://doi.org/10.21272/mmi.2020.3-26

Czyżewski, B., Matuszczak, A., \& Miskiewicz, R. (2019). Public Goods Versus The Farm Price-Cost Squeeze: Shaping the Sustainability of the EU's Common Agricultural Policy. Technological and Economic Development of Economy, 25(1), 82-102. https://doi.org/10.3846/tede.2019.7449

Czyżewski, B., Matuszczak, A., Polcyn, J., Smędzik-Ambroży, K., \& Staniszewski, J. (2020). Deadweight Loss in Environmental Policy: The Case of the European Union Member States. Journal of Cleaner Production, 260, 121064. https://doi.org/10.1016/j.jclepro.2020.121064

Dalevska, N. (2013). Methodological issues of social order relationships analysis in categorial structures of international political economy. Economic Annals-XXI, 11-12(1), 12-15.

Dalevska, N., Khobta, V., Kwilinski, A., \& Kravchenko, S. (2019). A Model for Estimating Social and Economic Indicators of Sustainable Development. Entrepreneurship and Sustainability Issues, 6(4), 1839-1860. https://doi.org/10.9770/jesi.2019.6.4(21)

Dementyev, V. V. (2013). On Some Peculiarities of the Subject of Institutional Theory. Journal of Institutional Studies, 5(3), 5-13.

Dementyev, V. V. (2015). Institutional Political Economy: Where to Start? Journal of Institutional Studies, 7(1), 25-44. https://doi.org/10.17835/2076-6297.2015.7.1.025-044

Dementyev, V.V., \& Scherbakov, A. P. (2017). Profit And Economic Growth. Terra Economicus, 15(3), 75-91. https://doi.org/10.23683/2073-6606-2017-15-3-75-91

Dementyev, V. V. (2019). Innovation: Between the Coase Theorem and the Hobbes Theorem. Journal of Institutional Studies, 11(1), 95-114. https://doi.org/10.17835/2076-6297.2019.11.1.095-114

Dementyev, V.V., \& Kwilinski, A. (2020). Institutsionalnaya sostavlyayuschaya izderzhek proizvodstva [Institutional Component of Production Costs]. Journal of Institutional Studies, 12(1), 100-116. https://doi.org/10.17835/2076-6297.2020.12.1.100-116 [in Russian].

Dinsmoor, J. A. (1995). Mentalnye prostranstva s funkcional'noj tochki zreniya. Yazyk i intellekt [Mental Spaces From a Functional Point of View. Language and Intelligence]. Moscow: Progress. [in Russian].

Drozdz, W., Miskiewicz, R., Pokrzywniak, J., \& Elzanowski, F. (2019). Urban Electromobility in the Context of Industry 4.0. Torun: Wydawnictwo Adam Marszalek. 
Drozdz, W., Marszalek-Kawa, J., Miskiewicz, R., \& Szczepanska-Waszczyna, K. (2020). Digital Economy in the Comporary World. Torun: Wydawnictwo Adam Marszalek.

Dzwigol, H. (2019a). The Concept of the System Approach of the Enterprise Restructuring Process. Virtual Economics, 2(4), 46-70. https://doi.org/10.34021/ve.2019.02.04(3)

Dzwigol, H. (2019b). Research Methods and Techniques in New Management Trends: Research Results. Virtual Economics, 2(1), 31-48. https://doi.org/10.34021/ve.2019.02.01(2)

Dzwigol, H. (2020a). Innovation in Marketing Research: Quantitative and Qualitative Analysis. Marketing and Management of Innovations, 1, 128-135. http://doi.org/10.21272/mmi.2020.1-10

Dzwigol, H. (2020b). Methodological and Empirical Platform of Triangulation in Strategic Management. Academy of Strategic Management Journal, 19(4), 1-8.

Dzwigol, H. (2020c). Tools for Adjusting Research Methods and Techniques to Research Processes. Economic Herald of the Donbas, 4(62), 110-118.

Dzwigol, H. (2020d). Interim Management as a New Approach to the Company Management. Review of Business and Economics Studies, 8(1), 20-26. https://doi.org/10.26794/2308-944X-2020-8-1-2026

Dzwigol, H. (2021). Meta-Analysis in Management and Quality Sciences. Marketing and Management of Innovation, 1, 324-335. https://doi.org/10.21272/mmi.2021.1-25

Dzwigol, H., \& Dźwigoł-Barosz, M. (2018). Scientific Research Methodology in Management Sciences. Financial and Credit Activity: Problems of Theory and Practice, 2(25), 424-437. https://doi.org/10.18371/fcaptp.v2i25.136508

Dzwigol, H., \& Dzwigol-Barosz, M. (2020a). Sustainable Development of the Company on the Basis of Expert Assessment of the Investment Strategy. Academy of Strategic Management Journal, 19(5), 1-7.

Dzwigol, H., \& Dzwigol-Barosz, M. (2020b). Determinants of the World Investment Market Development in the Context of Global Transformations. In Khalid S. Soliman (Ed.), Proceedings of the 36th International Business Information Management Association (IBIMA) 4-5 November 2020 (pp. 9109-9116). Granada, Spain: IBIMA Publishing.

Dzwigol, H., Shcherbak, S., Semikina, M., Vinichenko, O., \& Vasiuta, V. (2019a). Formation of Strategic Change Management System at an Enterprise. Academy of Strategic Management Journal, 18(SI1), 1-8.

Dzwigol, H., Aleinikova, O., Umanska, Y., Shmygol, N., \& Pushak, Y. (2019b). An Entrepreneurship Model for Assessing the Investment Attractiveness of Regions. Journal of Entrepreneurship Education, 22(1S), 1-7.

Dzwigoł, H., Dzwigoł-Barosz, M., Zhyvko, Z., Miskiewicz, R., \& Pushak, H. (2019c). Evaluation of the Energy Security as a Component of National Security of the Country. Journal of Security and Sustainability Issues, 8(3), 307-317. http://doi.org/10.9770/jssi.2019.8.3(2)

Dzwigol, H., Dźwigoł-Barosz, M., \& Kwilinski, A. (2020a). Formation of Global Competitive Enterprise Environment Based on Industry 4.0 Concept. International Journal of Entrepreneurship, 24(1), 1-5.

Dzwigol, H., Dzwigol-Barosz, M., Miskiewicz, R., \& Kwilinski, A. (2020b). Manager Competency Assessment Model in the Conditions of Industry 4.0. Entrepreneurship and Sustainability Issues, 7(4), 2630-2644. https://doi.org/10.9770/jesi.2020.7.4(5)

Frank, A., \& Gills, B. (1994). The World System: Five Hundred Years or Five Thousand? L., N.Y.: Routledge. 
Freeman, C., \& Louca, F. (2001). As Time Goes By: From the Industrial Revolutions to the Information Revolution. New York : Oxford University Press.

Gorynia, M., Trąpczyński, P., \& Bytniewski, S. (2019). The Concepts of Strategy and Business Models in Firm Internationalization Research: Towards a Research Agenda. International Entrepreneurship Review, 5(2), 7-21. https://doi.org/10.15678/ier.2019.0502.01

Gorynia, M. (2019). Competition and Globalisation in Economic Sciences. Selected Aspects. Economics and Business Review, 5(3), 118-133. https://doi.org/10.18559/ebr.2019.3.7

Gould, S. J. (1986). V zashchitu koncepcii preryvistogo dvizheniya. Katastrofy i istoriya Zemli: Novyj uniformizm [For defense of the concept of intermittent motion. Disasters and Earth History: A New Uniformism]. Moscow: MIR. [in Russian].

Habermas, J. (1991). The Theory of Communicative Action. Vol. 2. Cambridge: Polity Press.

Kashchena, N., Solokha, D., Trushkina, N., Potemkin, L., \& Mirkurbanova, R. (2019). Use of multi-agent simulation modeling for predicting the sales of wholesale trade companies. Journal of Management Information and Decision Sciences, 22(4), 483-488.

Kaźmierczyk, J., \& Chinalska, A. (2018). Flexible forms of employment, an opportunity or a curse for the modern economy? Case study: banks in Poland. Entrepreneurship and Sustainability Issues 6(2), 782-798. https://doi.org/10.9770/jesi.2018.6.2(21)

Kharazishvili, Y., Kwilinski, A., Grishnova, O., \& Dzwigol, H. (2020). Social Safety of Society for Developing Countries to Meet Sustainable Development Standards: Indicators, Level, Strategic Benchmarks (with Calculations Based on the Case Study of Ukraine). Sustainability, 12(21), 8953. https://doi.org/10.3390/su12218953

Kharazishvili, Y., Kwilinski, A., Sukhodolia, O., Dzwigol, H., Bobro, D., \& Kotowicz, J. (2021). The Systemic Approach for Estimating and Strategizing Energy Security: The Case of Ukraine. Energies, 14(8), 2126. https://doi.org/10.3390/en14082126

Koibichuk, V., Ostrovska, N., Kashiyeva, F., \& Kwilinski, A. (2021). Innovation Technology and Cyber Frauds Risks of Neobanks: Gravity Model Analysis. Marketing and Management of Innovations, 1, 253-265. http://doi.org/10.21272/mmi.2021.1-19

Koev, S.R., Tryfonova, O., Inzhyievska, L., Trushkina, N., \& Radieva, M. (2019a). Management of Domestic Marketing of Service Enterprises. IBIMA Business Review, 681709. https://doi.org/ 10.5171/2019.681709

Koev, S.R., Tryfonova, O., Inzhyievska, L., Trushkina, N., \& Radieva, M. (2019b). Contact personnel assessment as a prerequisite for introduction of internal marketing system. In Khalid S. Soliman (Ed.), Proceedings of the 33rd International Business Information Management Association Conference, IBIMA 2019: Education Excellence and Innovation Management through Vision 2020 (pp. 6497-6510). Granada, Spain: IBIMA Publishing

Kondratenko, V., Okopnyk, O., Ziganto, L., \& Kwilinski, A. (2020). Innovation Development of Public Administration: Management and Legislation Features. Marketing and Management of Innovations, 1, 87-94. https://doi.org/10.21272/mmi.2020.1-06

Kuzior, A., Kwilinski, A., \& Tkachenko, V. (2019). Sustainable Development of Organizations Based on the Combinatorial Model of Artificial Intelligence. Entrepreneurship and Sustainability, 7(2), 13531376. http://doi.org/10.9770/jesi.2019.7.2(39)

Kvilinskyi, O.S. (2012). Formirovanie dopolnitel'nyh preimushchestv funkcionirovaniya i razvitiya malyh predpriyatij [Formation of Additional Benefits of Operation and Development of Small Enterprises]. Economy of Industry, 3-4(59-60), 140-147. [in Russian]. 
Kvilinskyi, O., \& Kravchenko, S. (2016). Optimization of Innovative Project Realization Conditions. Zeszyty Naukowe Politechniki Poznańskiej. Organizacja i Zarzqqdzanie, 70, 101-111.

Kwilinski, A. (2018a). Mechanism of Formation of Industrial Enterprise Development Strategy in the Information Economy. Virtual Economics, 1(1), 7-25. https://doi.org/10.34021/ve.2018.01.01(1)

Kwilinski, A. (2018b). Mechanism of Modernization of Industrial Sphere of Industrial Enterprise in Accordance with Requirements of the Information Economy. Marketing and Management of Innovations, 4, 116-128. http://doi.org/10.21272/mmi.2018.4-11

Kwilinski, A. (2019). Implementation of Blockchain Technology in Accounting Sphere. Academy of Accounting and Financial Studies Journal, 23(SI2), 1-6.

Kwilinski, A., Tkachenko, V., \& Kuzior, A. (2019a). Transparent Cognitive Technologies to Ensure Sustainable Society Development. Journal of Security and Sustainability Issues, 9(2), 561-570 http://doi.org/10.9770/jssi.2019.9.2(15)

Kwilinski, A., Drobyazko, S., \& Derevyanko, B. (2019b). Synergetic and Value Effects in Corporate Mergers and Acquisitions of International Companies. In Khalid S. Soliman (Ed.), Proceedings of the 34th International Business Information Management Association Conference (IBIMA) 13-14 November 2019. Vision 2025: Education Excellence and Management of Innovations through Sustainable Economic Competitive Advantage in 2019 (pp. 9467-9471). Madrid, Spain: IBIMA Publishing.

Kwilinski, A., Dalevska, N., Kravchenko, S., Hroznyi, I., Kovalenko, I. (2019c). Formation of the Entrepreneurship Model of E-Business in the Context of the Introduction of Information and Communication Technologies. Journal of Entrepreneurship Education, 22(SI1), 1528-2651-22-S1337: 1-7.

Kwilinski, A., Ruzhytskyi, I., Patlachuk, V., Patlachuk, O., \& Kaminska, B. (2019d). Environmental Taxes as a Condition of Business Responsibility in the Conditions of Sustainable Development. Journal of Legal, Ethical and Regulatory Issues, 22(SI2) 1544-0044-22-SI-2-354: 1-6.

Kwilinski, A., Volynets, R., Berdnik, I., Holovko, M., \& Berzin, P. (2019e). E-Commerce: Concept and Legal Regulation in Modern Economic Conditions. Journal of Legal, Ethical and Regulatory Issues, 22(SI2), 1544-0044-22-SI-2-357: 1-6.

Kwilinski, A., Pajak, K., Halachenko, O., Vasylchak, S., Pushak, Ya., \& Kuzior, P. (2019f). Marketing Tools for Improving Enterprise Performance in the Context of Social and Economic Security of the State: Innovative Approaches to Assessment. Marketing and Management of Innovations, 4, 172-181. http://doi.org/10.21272/mmi.2019.4-14

Kwilinski, A., Dzwigol, H., \& Dementyev, V. (2019f). Transnational Corporations as Entities of International Entrepreneurship. International Journal of Entrepreneurship, 23(SI4), 1-6.

Kwilinski, A., \& Kuzior, A. (2020). Cognitive Technologies in the Management and Formation of Directions of the Priority Development of Industrial Enterprises. Management Systems in Production Engineering, 28(2), 119-123. http://doi.org/10.1515/mspe-2019-0020

Kwilinski, A., Vyshnevskyi, O., \& Dzwigol, H. (2020a). Digitalization of the EU Economies and People at Risk of Poverty or Social Exclusion. Journal of Risk and Financial Management, 13(7), 142. https://doi.org/10.3390/jrfm13070142

Kwilinski, A., Zaloznova, Y., Trushkina, N., \& Rynkevych, N. (2020b). Organizational and Methodological Support for Ukrainian Coal Enterprises Marketing Activity Improvement. E3S Web of Conferences, 168, 00031. https://doi.org/10.1051/e3sconf/202016800031 
Kwilinski, A., Dielini, M., Mazuryk, O., Filippov, V., \& Kitseliuk, V. (2020c). System Constructs for the Investment Security of a Country. Journal of Security and Sustainability Issues, 10(1), 345-358. https://doi.org/10.9770/jssi.2020.10.1(25)

Kwilinski, A., Shteingauz, D., \& Maslov, V. (2020d). Financial and Credit Instruments for Ensuring Effective Functioning of the Residential Real Estate Market. Financial and Credit Activities: Problems of Theory and Practice. 3(34), 133-140. https://doi.org/10.18371/fcaptp.v3i34.215448

Kwilinski, A., Slatvitskaya, I., Dugar, T., Khodakivska, L., \& Derevyanko, B. (2020e). Main Effects of Mergers and Acquisitions in International Enterprise Activities. International Journal of Entrepreneurship, 24(Special Issue), 1-8.

Kwilinski, A., Litvin, V., Kamchatova, E., Polusmiak, J., \& Mironova, D. (2021). Information Support of the Entrepreneurship Model Complex with the Application of Cloud Technologies. International Journal of Entrepreneurship, 25(1), 1-8.

Kyrylov Y, Hranovska V, Boiko V, Kwilinski A, \& Boiko L. (2020). International Tourism Development in the Context of Increasing Globalization Risks: On the Example of Ukraine's Integration into the Global Tourism Industry. Journal of Risk and Financial Management, 13(12), 303. https://doi.org/10.3390/jrfm13120303

Lakhno, V., Malyukov, V., Bochulia, T., Hipters, Z., Kwilinski, A., \& Tomashevska, O. (2018). Model of Managing of the Procedure of Mutual Financial Investing in Information Technologies and Smart City Systems. International Journal of Civil Engineering and Technology, 9(8), 1802-1812.

Legatum Institute. (2019). 2019 The Legatum Prosperity Index. Retrieved from https://li.com/reports/2019-legatum-prosperity-index/

Lyulyov, O., \& Pimonenko, T. (2017a). Lotka-Volterra Model as an Instrument of the Investment and Innovative Processes Stability Analysis. Marketing and Management of Innovations, 1, 159-169. https://doi.org/10.21272/mmi.2017.1-14

Lyulyov, O., \& Shvindina, H. (2017b). Stabilisation Pentagon Model: Application in the Management at Macro- and Micro-Levels. Problems and Perspectives in Management, 15(3), 42-52. https://doi.org/10.21511/ppm.15(3).2017.04

Lyulyov, O., Chygryn, O., \& Pimonenko, T. (2018). National Brand as a Marketing Determinant of Macroeconomic Stability. Marketing and Management of Innovations, 3, 142-152, https://doi.org/10.21272/mmi.2018.3-12

Lyulyov, O., Us, Y., Pimonenko, T., Kwilinski, A., Vasylieva, T., Dalevska, N., Polcyn, J., \& Boiko, V. (2020a). The Link Between Economic Growth and Tourism: Covid-19 Impact. In Khalid S. Soliman (Ed.), Proceedings of the 36th International Business Information Management Association (IBIMA) 4-5 November 2020. (pp. 8070-8086). Granada, Spain: IBIMA Publishing.

Lyulyov, O., Pimonenko, T., Kwilinski, A., Us, Y., Arefieva, O., Akimov, O., \& Pudryk, D. (2020b). Government Policy on Macroeconomic Stability: Case for Low- and Middle- Income Economies. In Khalid S. Soliman (Ed.), Proceedings of the 36th International Business Information Management Association (IBIMA) 4-5 November 2020 (pp. 8087-8101). Granada, Spain: IBIMA Publishing.

Lyulyov, O., Pimonenko, T., Kwilinski, A., Dzwigol, H., Dzwigol-Barosz, M., Pavlyk, V., \& Barosz, P. (2021a). The Impact of the Government Policy on the Energy Efficient Gap: The Evidence from Ukraine. Energies, 14(2), 373. https://doi.org/10.3390/en14020373

Lyulyov, O., Pimonenko, T., Kwilinski, A., \& Us, Y. (2021b). The Heterogeneous Effect of Democracy, Economic and Political Globalisation on Renewable Energy. E3S Web of Conferences, 250, 03006. https://doi.org/10.1051/e3sconf/202125003006 
Melnychenko, O. (2019). Application of artificial intelligence in control systems of economic activity. Virtual Economics, 2(3), 30-40. https://doi.org/10.34021/ve.2019.02.03(3)

Melnychenko, O. (2020). Is Artificial Intelligence Ready to Assess an Enterprise's Financial Security? Journal of Risk and Financial Management, 13(9), 191. https://doi.org/10.3390/jrfm13090191

Melnychenko, O. (2021). The Energy of Finance in Refining of Medical Surge Capacity. Energies, 14, 210. https://doi.org/10.3390/en14010210

Mlaabdal, S., Chygryn, O., Kwilinski, A., Muzychuk, O., \& Akimov, O. (2020). Economic Growth and Oil Industry Development: Assessment of the Interaction of National Economy Indicators. In Khalid S. Soliman (Ed.), Proceedings of the 36th International Business Information Management Association (IBIMA) 4-5 November 2020 (pp. 8102-8114). Granada, Spain: IBIMA Publishing.

Miskiewicz, R. (2017a). Knowledge in the Process of Enterprise Acquisition. Progress in Economic Sciences, 4, 415-432. https://doi.org/10.14595/PES/04/029

Miskiewicz, R. (2017b). Knowledge Transfer in Merger and Acquisition Processes in the Metallurgical Industry. Warsaw: PWN.

Miskiewicz, R. (2018). The Importance of Knowledge Transfer on the Energy Market. Polityka Energetyczna, 21(2), 49-62. http://dx.doi.org/10.24425\%2F122774

Miskiewicz, R. (2019). Challenges Facing Management Practice in the Light of Industry 4.0: The Example of Poland. Virtual Economics, 2(2), 37-47. https://doi.org/10.34021/ve.2019.02.02(2)

Miskiewicz, R. (2020a). Internet of Things in Marketing: Bibliometric Analysis. Marketing and Management of Innovations, 3, 371-381. http://doi.org/10.21272/mmi.2020.3-27

Miskiewicz, R. (2020b). Efficiency of Electricity Production Technology from Post-Process Gas Heat: Ecological, Economic and Social Benefits. Energies, 13(22), 6106. https://doi.org/10.3390/en13226106

Miśkiewicz, R, \& Wolniak, R. (2020). Practical Application of the Industry 4.0 Concept in a Steel Company. Sustainability, 12(14), 5776. https://doi.org/10.3390/su12145776

Miśkiewicz, R. (2021). The Impact of Innovation and Information Technology on Greenhouse Gas Emissions: A Case of the Visegrád Countries. Journal of Risk and Financial Management, 14(2), 59. https://doi.org/10.3390/jrfm14020059

Pająk, K., Kamińska, B., \& Kvilinskyi, O. (2016). Modern Trends of Financial Sector Development under the Virtual Regionalization Conditions. Financial and Credit Activity: Problems of Theory and Practice, 2(21), 204-217. https://doi.org/10.18371/fcaptp.v2i21.91052

Pająk, K., Kvilinskyi, O., Fasiecka, O., \& Miskiewicz, R. (2017). Energy security in regional policy in Wielkopolska region of Poland. Economics and Environment, 2(61), 122-138.

Parsons, T. (1977). Social systems and the evolution of action theory. New York: Free Press.

Pimonenko, T., \& Lyulyov, O. (2019). Marketing strategies of green investments: main provisions and basic features. Herald of Ternopil National Economic University, (1), 177-185. doi:https://doi.org/10.35774/visnyk2019.01.177.

Porokhovskyi, O. (2012). Politychna ekonomiia na pochatku XXI stolittia [Political Economy at the Beginning of the XXI Century]. Ekonomichna teoriia, 2, 17-28. [in Ukranian].

Ponomarenko, T., Khudolei, V., Prokopenko, O., \& Klisinski, J. (2018a). Competitiveness of the information economy industry in Ukraine. Problems and Perspectives in Management, 16(1), 8595. http://dx.doi.org/10.21511/ppm.16(1).2018.08

Ponomarenko, T., Zinchenko, O., Khudoliei V., Prokopenko, O., \& Pawliszczy, D. (2018b). Formation of the Investment Envronment in Ukraine in the Context of European Integration: An Example of 
Poland. Investment Management and Financial Innovations, 15(1), 361-373. http://dx.doi.org/10.21511/imfi.15(1).2018.30

Prokopenko, O., \& Miskiewicz, R. (2020). Perception of "Green Shipping" in the Contemporary Conditions. Entrepreneurship and Sustainability Issues, 8(2), 269-284. https://doi.org/10.9770/jesi.2020.8.2(16)

Putnam, R., Leonardi, R., \& Nanetti, R. (2001). Tvorennia demokratii: Tradytsii hromadskoi aktyvnosti v suchasnii Italii [Making Democracy Work: Civic Traditions in Modern Italy]. Kyiv: Vyd-vo Solomii Pavlychko „Osnovy." [in Ukrainian].

Saługa, P.W., Szczepańska-Woszczyna, K., Miśkiewicz, R., \& Chłąd, M. (2020). Cost of Equity of CoalFired Power Generation Projects in Poland: Its Importance for the Management of DecisionMaking Process. Energies, 13(18), 4833. https://doi.org/10.3390/en13184833

Savchenko, T., Basiurkina, N., Rodina, O., \& Kwilinski, A. (2019). Improvement of the Assessment Methods of Product Competitiveness of the Specialized Poultry Enterprises. Management Theory and Studies for Rural Business and Infrastructure Development, 41(1), 43-61. https://doi.org/10.15544/mts.2019.05

Schumpeter, J. (1995). Kapitalizm, socializm i demokratiya [Capitalism, Socialism and Democracy]. Moscow: Ekonomika. [in Russian].

Schubert, K. (2004). Logika struktury, logika sub"ektov i logika innovacii: Koncepcii setej i analiz sfer politiki [Structure Logic, Subject Logic and the Logic of Innovation: Network Concepts and Policy Areas Analysis]. In N. Konegen \& K. Shubert (Eds.), Metodicheskie podhody politologicheskogo issledovaniya i metateoreticheskie osnovy politicheskoj teorii [Methodological Approaches of Political Science Research and Metatheoretical Foundations of Political Theory] (pp. 199-219). Moscow: ROSSPEN. [in Russian].

Shmygol, N., Łuczka, W., Trokhymets, O., Pawliszczy, D., \& Zavgorodniy, R. (2020). Model of diagnostics of resource efficiency in oil and gas sector of economy of Ukraine. E3S Web of Conferences, 166, 13005. https://doi.org/10.1051/e3sconf/202016613005

The World Bank. (2019). Data. Retrieved from http://data.worldbank.org/indicator

Tkachenko, V., Kwilinski, A., Korystin, O., Svyrydiuk, N., \& Tkachenko, I. (2019a). Assessment of Information Technologies Influence on Financial Security of Economy. Journal of Security and Sustainability, 8(3), 375-385. http://doi.org/10.9770/jssi.2019.8.3(7)

Tkachenko, V., Kwilinski, A., Klymchuk, M., \& Tkachenko, I. (2019b). The Economic-Mathematical Development of Buildings Construction Model Optimization on the Basis of Digital Economy. Management Systems in Production Engineering, 27(2), 119-123. http://doi.org/10.1515/mspe2019-0020

Tkachenko, V., Kwilinski, A., Tkachenko, I., \& Puzyrova, P. (2019c). Theoretical and Methodical Approaches to the Definition of Marketing Risks Management Concept at Industrial Enterprises. Marketing and Management of Innovations, 2, 228-238. http://doi.org/10.21272/mmi.2019.2-20

Tkachenko, V., Kwilinski, A., Kaminska, B., Tkachenko, I., \& Puzyrova, P. (2019d). Development and Effectiveness of Financial Potential Management of Enterprises in Modern Conditions. Financial and Credit Activity: Problems of Theory and Practice, 3(30), 85-94. https://doi.org/10.18371/fcaptp.v3i30.179513

Tkachenko, V., Kuzior, A., \& Kwilinski, A. (2019e). Introduction of Artificial Intelligence Tools into the Training Methods of Entrepreneurship Activities. Journal of Entrepreneurship Education, 22(6), 110. 
Trushkina, N. (2019). Development of the information economy under the conditions of global economic transformations: features, factors and prospects. Virtual Economics, 2(4), 7-25. https://doi.org/10.34021/ve.2019.02.04(1)

Trushkina, N., Abazov, R., Rynkevych, N., \& Bakhautdinova, G. (2020). Digital Transformation Organizational Culture under Conditions of the Information Economy. Virtual Economics, 3(1), 738. https://doi.org/10.34021/ve.2020.03.01(1)

United Nations Development Programme. (2019) Human Development Report 2019. Retrieved from http://hdr.undp.org/en/content/human-development-report-2019

Wallerstein, I. (1983). The Three Instances of Hegemony in the History of the Capitalist WorldEconomy. International Journal of Comparative Sociology, 24(1-2), 100-108.

Wallerstein, I. M. (2008). Istoricheskij kapitalizm. Kapitalisticheskaya civilizaciya [Historical Capitalism with Capitalist Civilization]. Moscow: Tovarishchestvo nauchnyh zdanij KMS. [in Russian].

Weber, M. (1978). Economy and Society. Vol. 1. Berkeley: University of California Press.

World Intellectual Property Organization. (2019). WIPO IP Facts and Figures 2019. Retrieved from http://www.wipo.int/edocs/pubdocs/en/wipo_pub_943_2019.pdf

World Economic Forum. (2019). The Global Competitiveness Report 2019. Retrieved from https://www.weforum.org/reports/how-to-end-a-decade-of-lost-productivity-growth

Wyrwa, J., \& Kaźmierczyk, J. (2020). Conceptualizing job satisfaction and its determinants: A systematic literature review. Ekonomicheskaya Sotsiologiya, 21(5), 138-168. 